\title{
Africana on Microfilm
}

A Microfilm of the Taveta Chronicle, I 895-1901, concerning the Taveta of Kenya, with an introduction by A. T. Matson, has recently been issued by Micro Methods Ltd., East Ardsley, Wakefield, Yorkshire, in the African Studies Association of the United Kingdom 'Sources Relating to Africa ' series. Africana reproduced by Micro Methods Ltd., include oral literature in African vernaculars, rare periodicals, rare linguistic material, newspapers in African vernaculars, rare British Official Publications, unpublished historical records, and collections of rare African pamphlets.

\section{Forthcoming Bibliographic Publications of the African Section, Library of Congress}

THE African Section of the Library of Congress has recently compiled a guide to serial publications relating to Africa South of the Sahara and has four other bibliographic studies in preparation. Sub-Saharan Africa; A Guide to Serials, now in press and scheduled for publication in 1970 , records 4,670 periodicals in western languages or in African languages in the Roman alphabet. Some are not devoted entirely to Africa but carry relevant articles with sufficient regularity. Islam in Africa South of the Sahara; An Annotated Guide, scheduled for publication in late 1970 or early 1971 , will cover a selection of books and periodical articles on the political, social, economic, and cultural influence of Islam from the seventh century. Botswana, Lesotho, Swaziland; A Guide to Official Publications of the Former High Commission Territories, $1868-1968$, scheduled for publication in 1970 , includes documents of the territorial and national governments from the beginning of British suzerainty to 1968 , when the last territory achieved its independence. French-Speaking Central Africa; $A$ Guide to Official Publications, a selection of published documents issued by the former federation of French Equatorial Africa and by colonial and independent governments of Burundi, Cameroon, Central African Republic, Chad, Congo (Brazzaville), Congo (Kinshasa), Gabon, and Rwanda, is scheduled for publication in late r 970 or early 1971. East Africa; $A$ Guide to Official Publications of Kenya, Tanzania, and Uganda, publication planned for 1972, will include material on former British and German administrations as well as documents of the three national governments.

\section{Ohio University Center for International Studies: Occasional Papers}

THE African Studies Program of the Center for International Studies, Ohio University is publishing a new Africa Series of Occasional Papers. The first six are now available and may be obtained from: Center for International Studies, 98 University Terrace, Ohio University, Athens, Ohio 45701 , U.S.A.

\section{Archives in East and Central Africa}

THE inaugural conference of the East and Central Africa Regional Branch of the International Council on Archives (EARBICA) was held in Nairobi from 9 to in June 1969. This is the second regional branch of the council and groups the following Member States: Burundi, Ethiopia, Kenya, Malawi, Rwanda, Somalia, Sudan, Tanzania, Uganda, Zambia, and the East African Community.

EARBICA's objectives, as set forth in the fourteen resolutions adopted in Nairobi, are: to establish, maintain, and strengthen relations between its Member States in the field of archives; to promote the preservation and protection of the archival heritage of the region; to publicize the use of archives and facilitate access to them; to promote and co-ordinate activities relating to archives; to sponsor training for archivists; to co-operate with other organizations or institutions concerned with documentation. 